\section{The moderating effect of information technology capabilities on the relationship between marketing mix and corporate entrepreneurship}

\author{
Fatima Ghezali and Abdessamad Boudi \\ Laboratory Economic Studies and Local Development Sud Quest, \\ University of Tahri Mohamed Bechar, Bechar, Algeria
}

\begin{abstract}
Purpose - The purpose of this paper is to investigate the relationship between marketing mix (MM), information technology capabilities (ITCAP) and corporate entrepreneurship (CE). Additionally, the study has attempted to address the moderating influence of ITCAP on MM-CE relationship.

Design/methodology/approach - To achieve the objectives of the study, data was collected from managers working in the upper and middle departments in some major Algerian banks. To test the hypotheses of the study, simple regression and PROCESS macro with moderated multiple regression were used.

Findings - The results of the study revealed that the MM and ITCAP positively affect entrepreneurship, and the ITCAP of banks and their interaction with the MM contributed positively to promoting entrepreneurship for companies through the moderate influence of ITCAP on the relationship between the $\mathrm{MM}$ and $\mathrm{CE}$.

Research limitations/implications - It is very difficult to present the generalization of the results of this study because some of the major banks mainly drove the study sample. Therefore, researchers are encouraged to test the proposed propositions further.

Practical implications - The results of the study suggested that policymakers in the banking sector in Algeria seriously consider developing the MM for its direct role in the CE. Specifically, the moderate role of ITCAP indicated that an effective alignment of the bank's ITCAP with elements of the MM could enhance the entrepreneurship position of the bank. Therefore, it is necessary to pay attention to the importance of these factors to foster entrepreneurship in the services sector.

Originality/value - The role of MM in CE has been overlooked in the extant literature, especially in the emerging economies. In addition, this study extends the body of knowledge through evaluating the moderating role of ITCAP using the effect of interaction in PROCESS macro with moderated multiple regression for path analysis.
\end{abstract}

Keywords Information management, Business process management, Banking strategies,

Management information systems, Marketing mix, Entrepreneurship,

Information technology capabilities, Corporate entrepreneurship

Paper type Research paper

(C) Fatima Ghezali and Abdessamad Boudi. Published in PSU Research Review. Published by Emerald Publishing Limited. This article is published under the Creative Commons Attribution (CC BY 4.0) licence. Anyone may reproduce, distribute, translate and create derivative works of this article (for both commercial and non-commercial purposes), subject to full attribution to the original publication and authors. The full terms of this licence may be seen at http://creativecommons.org/licences/by/4.0/ legalcode
Moderating effect of

information

technology

Received 16 December 2019 Revised 16 February 2020 Accepted 26 March 2020 


\section{PRR}

5,2

\section{Introduction}

Nations strengthen their economies by strengthening their financial institutions. There are many activists who collectively form the financial sector in Algeria. The banking sector accounts for $75 \%$ of Algeria's financial system. This interest is attributed to the fact that banks in developing countries, especially Algeria, are the sole and main supplier of credit to public and private investment projects. Interestingly, $80 \%$ of the market value is occupied by public banks in Algeria (Rapport Annuel 2017 Banque Central Algerie). Therefore, a timely investigation is needed regarding the performance of the banking industry. International and national businesses are constantly striving for growth, sustainability and entrepreneurship. Entrepreneurship is not only a challenge, but also a necessity for all types of businesses today, making the market more competitive. Researchers and practitioners mutually agreed that marketing mix (MM) is an important consideration in determining entrepreneurship (Hultman and Hills, 2011; Sulistyo and Siyamtinah, 2016).

For example, in their seminal works, Morris and Lewis (1995) as well as Carson et al. (1995) have established that MM plays an important role in enhancing entrepreneurship. Following these seminal works, researchers have reported that MM remains a prominent factor that potentially influences entrepreneurship in a variety of studies (Bilal and A1 Mqbali, 2015; Colbert, 2003; Miles and Darroch, 2006; Morris and Lewis, 1995; Arora and Nandkumar, 2012; Carson et al., 1995; Collinson and Shaw, 2001; Bocconcelli et al., 2018; Hultman and Hills, 2011; Knight, 2000; Solé, 2013; Barrett et al., 2000; Nasution et al., 2011; Kraus et al., 2010; Stokes, 2000). Relatedly, studies have also indicated the importance of information technology capabilities (ITCAP) for influencing entrepreneurship effectively (Chen et al., 2014; Chen et al., 2015; Trainor et al., 2011; Chae et al., 2018; Hoffman et al., 2018).

This study examines the extent of the impact of ITCAP on the relationship between MM and entrepreneurship in the Algerian banking sector. The study also assesses the extent of adoption of the public administration in the Algerian banks to integrate information technology (IT) in their daily operations and research the degree of confidence in the IT of banking operations in Algeria. To achieve the highest degree of profitability and credibility of these banks, the results of this study may be useful in terms of proposing some appropriate solutions that may lead to the development of work in the banking sector, increase its efficiency and formulate appropriate strategies achieved in to the end of the goals that banks seek to achieve.

\section{Theory and hypotheses development}

\section{Entrepreneurship}

Entrepreneurship is an important and promising field in the economies of developed and developing countries alike (Kuratko, 2007). Entrepreneurship contributes effectively to inclusive economic development in all countries, and the concept of "entrepreneurship" is a critical concept in the contemporary economy (Muñoz et al., 2011). Entrepreneurship is an ancient concept that was first used at the beginning of the 16th century. The concept then included the meaning of risk and the difficulties that accompanied the military exploration campaigns (Zahra and George, 2002), where the concept of entrepreneurship entered into economic activities in the early 18th century (Kuratko, 2007).

After reviewing several administrative literature (Walter et al., 2006; Urbano and Alvarez, 2014; Martens et al., 2018; Morris and Lewis, 1995), it was found that there is agreement between these groups of literature and that there are four characteristics of the leading organizations that have been adopted for testing in the practical aspect of the current research, and that these characteristics can work to improve the entrepreneurial performance of organizations. Zahra and George (2002) and Simba (2015) described 
creativity as the organization's efforts to find new opportunities and innovative solutions. It also means the organization's attitude toward the process of innovation and the extent of its preference for innovation, and includes the spirit of creativity and experience that produces a new product or service and improve technological processes, and creativity is one of the most important components of entrepreneurial behavior. As Muñoz et al. (2011) and Bhuian et al. (2005) pointed out that autonomy is that the creators and entrepreneurs of new ideas are independent in decision-making and free to work. This encourages them to make further efforts to achieve leadership for the organization through their technical and managerial abilities (Amit and Zott, 2001). Several studies (Lumpkin and Dess, 2001; Hacioglu et al., 2012) have confirmed that proactive approach is very effective in promoting entrepreneurship. Proactive organizations monitor trends and try to figure out the future requirements of existing customers and recognize changes in demand or perceive emerging problems that can lead to opportunities for new projects. To be successful entrepreneurs, they usually have the risk and the dangerous alternatives even if it means leaving the methods or products they were working on previously to obtain high financial returns (Shepherd et al., 2015). Organizations sometimes risk borrowing large amounts and commitment to large amounts of the organization's resources and the introduction of new products to new markets and investment in undiscovered technology (Ndubisi and Iftikhar, 2012).

\section{Marketing mix and corporate entrepreneurship}

Corporate entrepreneurship (CE) enhances the organization's market orientation through MM practices, because market-oriented organizations are in a unique position to predict the needs of customers and provide innovative and creative products and services to satisfy those needs (Bilal and Al Mqbali, 2015), and in addition to marketing, it enhances the organization's creative and innovative capabilities (Kivipõld and Vadi, 2013). Based on the above, the overlap between marketing and entrepreneurship and the impact of MM on CE can be illustrated.

Brouthers et al. (2015) stressed that the prominent nature of both marketing and entrepreneurship is the pursuit of opportunities to turn them into practical and market ideas. Each of the two areas is characterized by creative and innovative characteristics in its orientations and management approaches (Bocconcelli et al., 2018), and to achieve added value through investment in time, money, efforts and skills. Harrigan et al. (2012) and Knight (2000) also pointed out that many of the activities and actions implemented by entrepreneurs fall within the core concepts of marketing theory. According to the marketing theory, effective marketing is achieved when the organization succeeds in identifying new opportunities and adopting innovative approaches and approaches in marketing practices (MM) (Martin, 2009). On the other hand, marketing theory focuses on the need to take into account the characteristics of the changing environment and the pressure and variables involved (Wahab and Nagaty, 2017). Barrett et al. (2000) pointed out that the marketing activity that entrepreneurial marketers are eager to do is one that leads to growth. Marketing from the perspective of entrepreneurial organizations is not just a business function, but they use marketing as a path to achieve competitive advantage based on achieving excellence in their marketing programs and to raise the knowledge of these organizations distinct from customers, markets and technology (Bilal and Al Mqbali, 2015). Entrepreneurial marketers see the marketing function as the core and central function of the organization, which includes creativity and innovation (Kivipõld and Vadi, 2013).

However, literature on MM extends that its significant influence on $\mathrm{CE}$ has led to various outcomes (Lee, 2002; Lekmat et al., 2018; Nguyen, 2007; Oflac et al., 2015; Stokes, 2000;
Moderating
effect of
information
technology

103 
PRR

5,2

Blut et al., 2018; Bernik and Bowman, 2007; Whetten, 2014). Therefore, the present study proposed the following hypothesis:

H1. MM is positively related with $\mathrm{CE}$.

\section{Information technology capabilities and corporate entrepreneurship}

Oh et al. (2014) defined the capacity of IT as the ability of a company to acquire, deploy, collect and reconstruct IT resources to support and enhance business strategies and business processes. Chen et al. (2015) address the ITCAP that consists of IT operations and the ability to manage IT in studying the impact of ITCAP on corporate performance. O'Reilly et al. (2019) proposed the dynamic capabilities of IT that organizations should consider developing to achieve a competitive advantage. Many organizations use ITCAP as unparalleled valuable resources that help the organization gain a leading edge (Ramachandran and Ray, 2006; Haar and White, 2013; Bucktowar et al., 2015).

Similarly, literature also provides enormous support pertaining to the relationship between ITCAP and CE (Li et al., 2018; Mithas et al., 2011; Bharadwaj, 2000). The present study has attempted to investigate the relationship between ITCAP and CE because of the fact that ITCAP will vary from business to business (Ajayi, 2016), and should also be inimitable (Rehman et al., 2018; Sutton et al., 2007). Therefore, the researchers deemed it necessary to further investigate this relationship by proposing following hypothesis:

H2. ITCAP is positively related with $\mathrm{CE}$.

\section{Moderating role of information technology capabilities}

The main objective of the present study was to investigate the moderating effect of ITCAP on the relationship between MM and CE. The choice of ITCAP as a moderating variable was because of the following reasons.

First, the neglect of traditional marketing theories of the specificity of marketing in the environment of entrepreneurial organizations, and the lack of focus of major marketing processes and tools on the requirements of marketing activity in these organizations was a strong motivation. This served as the basis for studies that have been concerned with the mixing and overlap between marketing and entrepreneurship (Sulistyo and Siyamtinah, 2016). Similarly, Išoraite (2015) and Solé (2013) claimed the correlation between the MM and entrepreneurship. Barrett et al. (2000) and Goodale et al. (2011) claimed that convincing evidence does not exist that could support the idea that elements of the MM in companies directly contribute to the organization's excellence and leadership. Despite recent efforts by writers and researchers, there is still some ambiguity about the relationship between the MM and entrepreneurship. Clearly available evidence is research work conducted by Išoraitė (2015), Stokes (2000), Martin (2009), Bashar et al. (2012) and Wahab and Nagaty (2017). In these research studies, one can emphasize and highlight significant differences of opinion about the nature of the relationship between the MM and the leadership of organizations. Referring to these inconsistencies in previous research on the severed relationship, Baron and Kenny (1986) recommended that when the relationship between the predictor and the standard variable is found to be weak or inconsistent, a moderate variable should be introduced.

Second, the current study proposed that ITCAP can be a potential intermediate variable in the relationship between MM and CE, suggesting that the relationship between two variables is conditional or dependent on the level of the third variable. It is therefore 
suggested that the introduction of an intermediate variable in the relationship between two variables may allow specific understanding and prevent misleading conclusions (Wu and Zumbo, 2008). To better understand the inconsistent results between marketing strategies and the relationship of entrepreneurship, strategic management theory was of fundamental importance (Ireland et al., 2003).

Finally, the literature on strategic management has specifically suggested that ITCAP has the potential power to moderate the relationship between organizational strategies (such as MM and its components) and CE positively (Sexton, 2001; Ireland et al., 2003). Thus, it was hypothesized as under:

H3. The relationship between $\mathrm{MM}$ and $\mathrm{CE}$ will be stronger when ITCAP is incorporated.

\section{Methodology}

\section{Sample and data collection}

To test our hypotheses, we used a sample of 160 staff working in major banks active in Algeria. The survey method was used to collect data from these banks. We used the questionnaire as the main tool for collecting data from the study sample. The managers of the agencies and the heads of sections were considered the most appropriate to answer, because they are well informed about their banking strategies and therefore can respond accurately to the survey (Kivipõld and Vadi, 2013; Corneliu and Maria, 2013). To ensure that nonresponse bias was not a major concern in this study, independent samples $t$-test was performed following Pingsmann et al.'s (2000) suggestion. Specifically, respondents were divided into two groups based on those who responded to the first follow-up (early responders) and those who responded after the third follow-up (late responders). The composition of the collected sample is described in Table 1.

The researcher also handed over the questionnaire to the study sample by hand, to ensure mutual understanding of the respondents, and clarify them how to answer their

\begin{tabular}{llrr}
\hline Variables & Levels & No. & $(\%)$ \\
\hline Gender & Female & 78 & 52.7 \\
& Male & 70 & 47.3 \\
Age group & $20-30$ & 39 & 26.4 \\
& $31-40$ & 75 & 50.7 \\
Educational level & 41 and above & 34 & 23.0 \\
& Secondary & 2 & 1.4 \\
Job position & Obtain a certificate or diploma & 1 & 0.7 \\
& Graduate studies & 145 & 98 \\
& Director & 11 & 7.4 \\
Professional experience & Deputy director & 18 & 12.2 \\
& Chief Service & 38 & 25.7 \\
& Managerial staff & 81 & 54.7 \\
Total & Less than 5 years & 38 & 25.7 \\
& From 5 to 10 years & 39 & 26.4 \\
& From 10 to 15 years & 47 & 31.8 \\
& More than 15 years & 24 & 16.2 \\
& & 148 & 100
\end{tabular}

Moderating effect of information technology

105

Source: Researcher

Table 1.

Composition of the collected sample 
PRR

5,2

106

questions if necessary and to insure return. A total of 12 questionnaires were excluded for lack of statistical analysis for reasons of either the lack of seriousness and clarity in the answers or incomplete answers, so statistical analysis was carried out on only 148 questionnaires $(160-12=148)$.

After completing the questionnaires in the statistical analysis program, the following statistical tests were conducted on the data:

- the reliability of the scale was measured;

- Pearson correlation analysis and other descriptive statistical analyzes were conducted to test the correlation between independent and dependent variables; and

- PROCESS macro modeling was conducted to identify the effect of the moderator variables on the relationship between independent and dependent variables (Hayes and Rockwood, 2017).

\section{Measures}

Marketing mix. It incorporates seven main dimensions: service marketing mix elements (Oflac et al., 2015). The elements in this range reflect the extent to which new ideas are developed and implemented in the bank's MM. Service marketing from the viewpoint of workers, which included 28 paragraph, and has already been used by former researchers the same method. For example, see Yelkur (2000). This measure was used as adapted by Lee (2002) and the researchers adjusted it to fit the objectives of the present study.

Information technology capabilities. The ITCAP scale included five paragraphs: IT infrastructure including hardware and software (Chae et al., 2014), proprietary software and shared services, IT skills (Abro et al., 2011) and operations (Byrd and Turner, 2001).

Corporate entrepreneurship. Entrepreneurship, which refers to managers' attitudes to the extent to which the bank has taken the lead in banking (Kivipõld and Vadi, 2013). It encompasses four main dimensions: excellence and creativity, risk orientation, proactive orientation and independence (Lumpkin and Dess, 2001). This scale was used as adopted by Kivipõld and Vadi (2013). The researcher made the necessary adjustment to fit the objectives of the present study and included 16 paragraphs for the 4 dimensions (4 paragraphs for each dimension).

Ratings were based on a five-point Likert scale ranged from $1=$ strongly disagree to $5=$ strongly agree.

\section{Analytical procedures}

The present study used PROCESS macro modeling to test the theoretical model. PROCESS is an observed variable ordinary least squares and logistic regression path analysis modeling tool for SPSS and SAS (Hayes and Rockwood, 2017). It is widely used through the social, business and health sciences for estimating direct and indirect effects in single and multiple mediator models (parallel and serial), two and three way interactions in moderation models along with simple slopes and regions of significance for probing interactions and conditional indirect effects in moderated mediation models with a single or multiple mediators or moderators. The use of PROCESS is described and documented in Introduction to Mediation, Moderation, and Conditional Process Analysis, published by The Guilford Press (Bolin, 2014). PROCESS was written by Andrew F. Hayes. 


\section{Results and discussion}

Measurement model assessment

According to Hamid et al. (2011) and Henseler et al. (2012), for assessing measurement model, researchers need to determine individual item reliability and determine internal consistency, content validity, convergent validity and discriminant validity.

\section{Validity of the scale}

The Kolmogorov-Smirnov scale was used to measure whether the study variables were normally distributed (moderate) or not (Jarque and Bera, 1987). If the attribute Sig is less than 0.05 , the distribution is normal, and we can see from Table 2 that the value of the tabular Sig is less than 0.05 at $95 \%$ confidence level, and therefore all variables take the normal distribution.

\section{Reliability of the scale}

It was evaluated by calculating the total and partial Cronbach's alpha coefficient. It was greater than $60 \%$ for all independent, intermediate and dependent study variables, which indicates good reliability of the scale; the value of this coefficient ranging from 0 to 1 , and the value of the coefficient of stability (alpha) is an indicator of the degree of reliability of the internal scale (Goforth, 2015). The total alpha value for the study variables was $(76.2 \%)$. Alpha is good because it is above the minimum acceptable ratio $(60 \%)$ (Bonett and Wright, 2015). Table 2 shows the results of the test of the validity and reliability of the study scale.

The means, standard deviations and bivariate correlations for all variables are presented in Table 3. Moderation analysis with PROCESS was used to test the hypotheses, as suggested by Hayes and Rockwood (2017). In each regression, the control variables (bank age and size) were entered in Step 1. The independent variables (MM and ITCAP) were included in Step 2, followed by the interaction term of MM and ITCAP in Step 3. To reduce possible problems with multi-collinearity resulting from interaction terms, we centered the independent predictor variables prior to computing the interaction term. The correlations indicate that there are strong correlations between independent and dependent variables, all of which are significant at the level of significance of $1 \%$, which does not exceed the value of $90 \%$, and this indicates that these variables do not suffer from the problem of selfcorrelation between them, and therefore can continue the hypothesis test.

In the main effect model, regression coefficients estimate public relations across all levels observed for other predictions. In line with $H 1$, MM has a positive effect on creativity and excellence $(b=0.99, p \leq 0.01)$, risk tolerance $(b=1.04, p \leq 0.01)$, proactiveness $(b=0.77, p \leq$ 0.01 ) and independence ( $b=0.47, p \leq 0.01)$. $H 2$ was only partially supported. ITCAP has a

\begin{tabular}{lcccc}
\hline Variables & Items & $\begin{array}{c}\text { Test Kolmogorov- } \\
\text { Smirnov }\end{array}$ & $\begin{array}{c}\text { Sig. asymptotique } \\
\text { (bilaterale) }\end{array}$ & $\begin{array}{c}\text { Cronbach's } \\
\text { alpha }\end{array}$ \\
\hline MM & 07 & 0.18 & 0.000 & 0.87 \\
ITCAP & 05 & 0.17 & 0.000 & 0.89 \\
Creativity and & 05 & 0.13 & 0.000 & 0.86 \\
excellence & & & 0.000 & 0.82 \\
Take risks & 02 & 0.14 & 0.000 & 0.86 \\
$\begin{array}{l}\text { Proactiveness } \\
\text { Independence }\end{array}$ & 03 & 0.24 & 0.000 & 0.76
\end{tabular}

Source: Researcher

\section{Moderating effect of information technology}

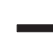


PRR
5,2

108

Table 3.

Descriptive statistics and correlations*

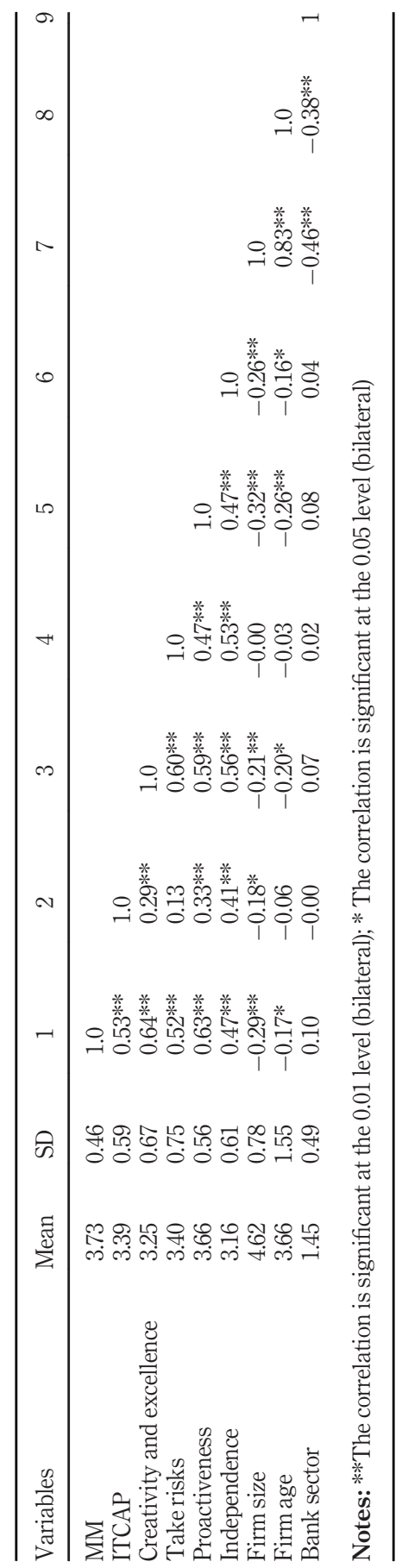


significant impact on independence $(b=0.22, p \leq 0.01)$. However, the effects of ITCAP on creativity and excellence, risk tolerance and proactive orientation were not significant in form 2 .

Table 4 presents the results of the overall interaction models (Model 3 ). The $R^{2}$, ranging from 0.38 to 0.92 , indicates a satisfactory level of explanation of the performance variables.

Differences in the values of coefficients for the main effects model and the overall interaction model result from the fact that the MM and ITCAP coefficients in the latter model estimate conditional relationships (Prado et al., 2014; Hayes, 2012).

The MM $\times$ ITCAP interaction terms are all positive and significant (creativity and excellence: $b=0.41, p \leq 0.05$; take risks: $b=0.79, p \leq 0.01$; and independence: $b=0.33, p \leq$ 0.05). The $\Delta R^{2}$ for the contingency vs main effects models are statistically significant. Thus, $H 3$ is supported with respect to most of the entrepreneurship measures. The interaction effect of MM $\times$ ITCAP on proactive orientation was, as expected, positive but not significant.

To obtain support for the hypothetical interaction relationships trend and examine the consistency of that trend across the ITCAP scale, we performed simple regression analyzes (Aiken and West, 1991). Table 3 shows that MM slopes are still positive across the entire ITCAP for models with excellence, innovation and take risks as dependent variables. However, slopes were much more positive at high levels of MM than at low levels. For proactiveness and independence models as dependent variables, slope analyses revealed a slightly weak slope of MM at low levels of ITCAP and a positive slope at high levels of ITCAP. Thus, ITCAP strengthens the positive effects of MM on excellence and creativity, take risks, proactiveness and independence.

\section{Testing moderation effect}

To test this hypothesis, the researcher used PROCESS macro modeling to find the effect of the moderator variables on the relationship between independent and dependent variables (Hayes and Rockwood, 2017) based on an estimate of three models. The first model aims (base model) to test the significance of the direct effect of the independent variable (MM) and the control variables (age, size and sector of the bank) in the dependent variable

\begin{tabular}{|c|c|c|c|c|c|}
\hline Independent variable & Creativity and excellence & Take risks & Proactiveness & Independence & \\
\hline Constant & $2.91 * * *$ & $1.89^{* * *}$ & $4.10 * * *$ & $3.83^{* * *}$ & \\
\hline $\begin{array}{l}\text { Main effects: } \\
\text { MM } \\
\text { ITCAP }\end{array}$ & $\begin{array}{l}1.09 \text { *** } \\
-0.07\end{array}$ & $\begin{array}{l}1.30^{* * * *} \\
-0.25^{* *}\end{array}$ & $\begin{array}{l}0.79 \text { *** } \\
-0.02\end{array}$ & $\begin{array}{l}0.50 * * * \\
0.19 *\end{array}$ & \\
\hline $\begin{array}{l}\text { Interaction effect: } \\
\mathrm{MM} \times \mathrm{ITCAP}\end{array}$ & $0.41 *$ & $0.79 *$ & 0.24 & $0.33^{*}$ & \\
\hline $\begin{array}{l}\text { Control variables: } \\
\text { Firm size } \\
\text { Firm age } \\
\text { Bank sector } \\
\left.R^{2} \text { (adjusted } R^{2}\right) \\
R^{2} \text { change (intr) } \\
F \\
N \\
\text { Notes: ***p } \leq 0.001 ;\end{array}$ & $\begin{array}{c}0.13 \\
-0.09^{*} \\
-0.18 \\
0.45 \\
0.01 * \\
19.55^{* * *} \\
148 \\
\leq 0.01 ; * 0 \leq 0.05 \text { (one-taile }\end{array}$ & $\begin{array}{c}0.35^{* *} \\
-0.08 \\
0.06 \\
0.38 \\
0.03^{*} \\
14.85^{* * *} \\
148\end{array}$ & $\begin{array}{c}-0.05 \\
-0.03 \\
-0.06 \\
0.43 \\
0.00 \\
18.32^{\text {**** }} \\
148\end{array}$ & $\begin{array}{c}-0.15 \\
0.02 \\
-0.07 \\
0.92 \\
0.01 \\
9.73^{* * * *} \\
148\end{array}$ & $\begin{array}{r}\text { Table 4. } \\
\text { Regression results } \\
\text { (unstandardized } \\
\text { coefficients) }\end{array}$ \\
\hline
\end{tabular}

Moderating effect of information technology 
PRR

5,2

Table 5.

Results of simple (unstandardized coefficients) slope analysis

(entrepreneurship). In the second model (reduced model), the researcher introduced the moderator variable (ITCAP) to test the direct impact of this variable in the model, while the third model aims (full model) to test the interaction between MM and ITCAP in the CE.

It is clear from Table 6 that the basic model is statistically significant, where the value of $\mathrm{F}$ for the model as a whole was 36.48 and at a significant level $(0.00)$, and the results show a direct significant impact of the MM in $\mathrm{CE}(\mathrm{H} 1)$.

It is also clear from the previous table, that the reduced model is statistically significant, where the value of $\mathrm{F}$ for the model as a whole is 29.06 at the level of significance 0.00 . As the ITCAP significantly affect entrepreneurship (H2), as the adding of ITCAP as an independent variable in the model did not lead to a change in the explanatory power of the model, where the adjusted determinant coefficient was $48 \%$, a decrease of $1 \%$ compared to the base model.

Recalling H3, it was stated that ITCAP moderates the relationship between MM and CE. As expected, Table 5 and Figure 1 suggest that the interaction term representing MM $\times$ ITCAP ( $b=0.44, t=2.75, p<0.005$ ) was significant. Thus, $H 3$ was fully supported. Following the guidelines of Hayes (2016), the information from path coefficients was used for plotting the moderating effect of ITCAP on relationship between MM and CE (Figure 1), suggesting improved relationship.

\begin{tabular}{lccc}
\hline & \multicolumn{3}{c}{ Slope for various levels of the moderator Variable } \\
& Low $(\mathrm{M}-\mathrm{D})$ & Moderate & High $(\mathrm{M}+\mathrm{D})$ \\
\hline $\mathrm{MM} \rightarrow$ Creativity and excellence & 0.84 & 1.09 & 1.33 \\
$\mathrm{MM} \rightarrow$ Take risks & 0.83 & 1.30 & 1.78 \\
$\mathrm{MM} \rightarrow$ Proactiveness & 0.15 & 0.79 & 1.25 \\
$\mathrm{MM} \rightarrow$ Independence & 0.04 & 0.50 & 0.97 \\
Note: ${ }^{\text {ITTCAP }}$ & & & \\
\end{tabular}

\begin{tabular}{lccc}
\hline Variable & Basic model & Reduced model & Full model \\
\hline Constant & 0.32 & 0.37 & 3.18 \\
Control variables: & & & \\
Firm size & 0.06 & 0.06 & 0.07 \\
Firm age & 0.05 & -0.05 & -0.04 \\
Banksector & -0.02 & -0.03 & -0.02 \\
Main effects: & & & \\
MM & 0.80 & 0.82 & 0.92 \\
$\quad$ ITCAP & & -0.02 & -0.03 \\
Interaction effect: & & & 0.44 \\
MM $\times$ ITCAP & 0.49 & 0.48 & 0.53 \\
$R^{2}$ & & & 0.02 \\
$R^{2}$ change (intr) & 36.48 & 29.06 & 26.60 \\
$F$ & 148 & 148 & 148 \\
$N$ & 0.000 & 0.000 & 0.000
\end{tabular}

Table 6.

Hierarchical regression models 


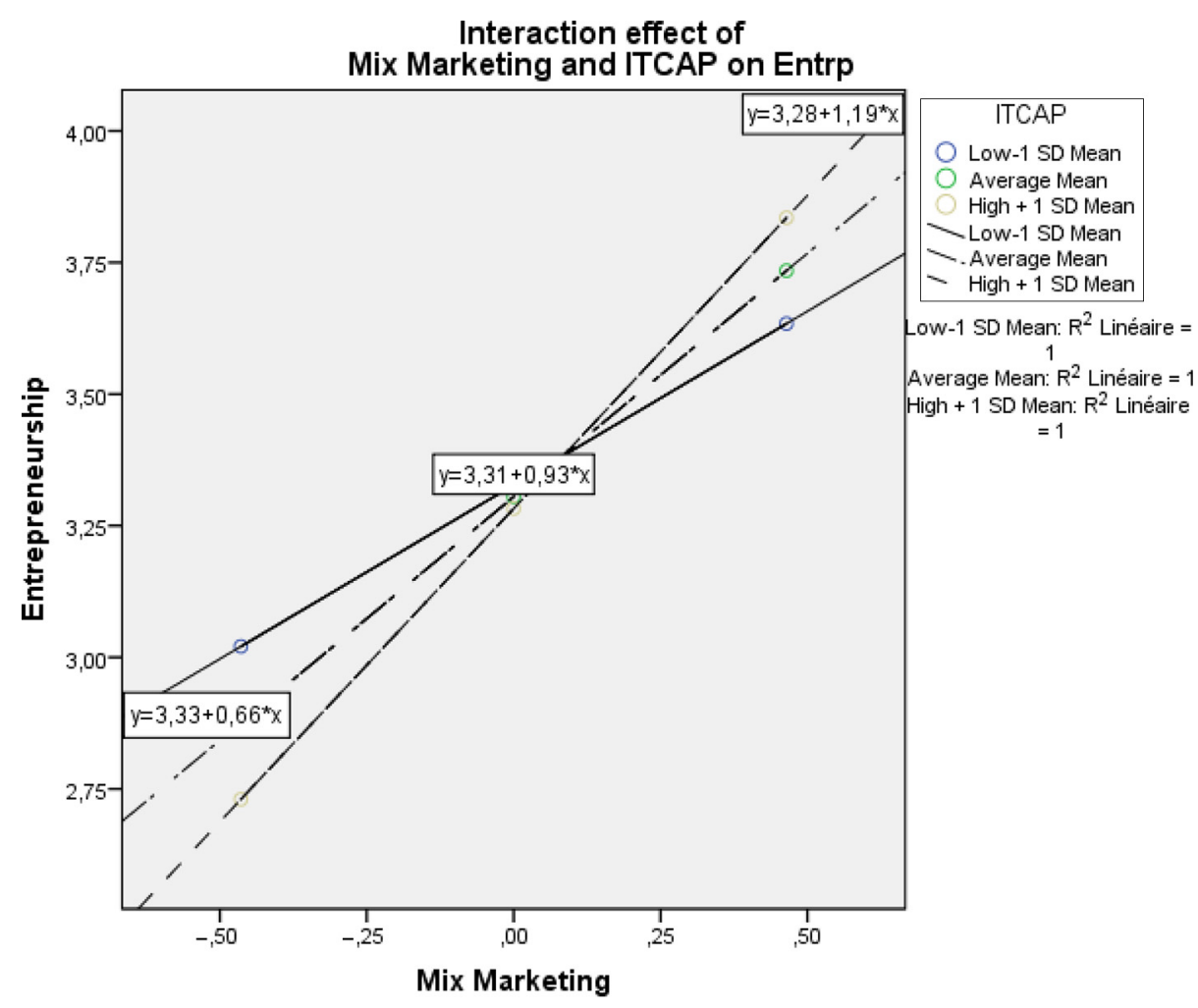

Moderating effect of information technology 111

Figure 1. Interaction effect of MM and ITCAP on entrepreneurship

As for the results of the full model, it indicated the significance of the model, where the value of $\mathrm{F}$ for the model as a whole was 26.06 at the level of 0.00 . Moreover, the results indicate that adding the effect of the moderator variable (ITCAP) in the model led to an increase in the interpretive power of the model. Where the value of the coefficient of determination $\left(R^{2}\right)$ $(53 \%)$ shows an increase of $4 \%$ compared to the reduced model, and an increase of $3 \%$ compared to the basic model. So the hypothesis that information ITCAP affects the relationship between MM and CE is accepted.

\section{Discussion}

This study examines how MM and ITCAP affect CE in the banking sector in Algeria. MM is a set of tools available to marketing managers to find the form and nature of the service provided to customers, which helps to develop long-term strategies and short-term programs (Jerome, 2019). ITCAP refers to a wide range of capabilities, components or various components used to process, store and distribute data and information (Chae et al., 2014).

\section{Marketing mix and corporate entrepreneurship}

Our study shows that the variables of entrepreneurship (creativity and excellence, risk, proactive dimension and autonomy) are influenced by MM. The results confirm previous studies on the efficiency of the alliance that shows that companies vary widely in their 
PRR

5,2

\section{2}

ability to access external resources and develop stable relationships (Miles et al., 2015). These differences lead to differences in marketing performance.

The results of this research give two theoretical contributions. First, they support the recent arguments of entrepreneurs regarding the importance of MM elements to achieve the dimensions of entrepreneurial behavior (Sulistyo and Siyamtinah, 2016). Second, we analyzed the overlap between marketing and entrepreneurship and not just the presence of MM. Entrepreneurial organizations use marketing as a path to achieve competitive advantage, based on achieving excellence in their marketing programs, highlighting that increased marketing capabilities lead to more effective identification of opportunities in banks.

\section{Information technology capabilities and corporate entrepreneurship}

In this study, no direct effect of ITCAP was found on creativity, excellence, risk tolerance or proactive orientation. This confirms the results of Hoffman et al. (2018), suggesting that ITCAP do not always make competitive advantage. We can conclude that the existence of ITCAP in itself does not promote a proactive approach to seize opportunities and entrepreneurial creativity. These findings support the general notion that entrepreneurship and ITCAP depend on the context in which they occur. For these reasons, electronic tools, IT and internet applications should not be considered a panacea for entrepreneurship (Dangolani, 2011).

However, we found that ITCAP has a very important direct impact on achieving entrepreneurial advantages. Obviously, the banks under study may use ITCAP as an effective means of seeking competitive advantages. The moderate significant impact of ITCAP on the dimension of independence makes it clear that ITCAP can maintain a creative approach, attract customers and improve the organization's reputation as a qualified technology provider. As such, ITCAP contributes to the relational capital (Chen et al., 2014) of companies, which can be considered as one of the most important factors in laying the foundations and pillars of leadership that give the organization the status of excellence (Karimi and Walter, 2016).

\section{Moderating effect of information technology capabilities on the marketing mix-corporate entrepreneurship relationship}

Pursuing an entrepreneurial behavior is a resource-consuming process (Karimi and Walter, 2016). Kuratko (2010) have argued that an organization's entrepreneurial capacity will be limited by its available resources and capabilities. In this study, the moderate role of ITCAP is shown. Comparing the reduced model to the complete model and the associated interaction term clearly reveals that ITCAP modifies the relationship between MM and entrepreneurship. We found that the two variables have a great interactive effect on excellence, creativity, risk, proactive and independence. Thus, ITCAP strengthens the relationship between MM and entrepreneurship. Therefore, Algerian banks can adopt an entrepreneurial approach based on marketing capabilities (elements of MM) and based on ITCAP to counter strategic change situations occurring in their environment (Weerawardena, 2003).

These results have important implications for the management of banks. Companies should note that the market orientation itself is not enough to compete in today's markets. $\mathrm{MM}$ is an entry ticket that offers higher efficiencies on performance. However, MM activities do not create value and should not be considered the primary force to reach and maintain a leading position. This also means that the researched banks should enhance their capacity in the IT framework to enhance the positive aspects and address the negative aspects of the 
link between the ITCAP and the indicators of entrepreneurship. Our findings indicate that the factors that influence entrepreneurial dimensions are not only MM activities but also ITCAP.

Conclusively, the current study provided many practical understanding regarding the $\mathrm{MM}$ and related practices in the banking sector in Algeria. First, the results found that MM practices are an important consideration for the bank's performance and leadership. Banks can make great efforts to maximize their performance by enhancing the perceptions of marketing managers about the dimensions of entrepreneurship. Second, banks in Algeria can maximize their performance by investing in marketing practices, for example banks may expand the role of ITCAP and support them at the managerial and marketing level, reward managers and marketers for bringing innovative ideas, allocating time and providing recognition. The current study has empirically proved that these factors are very critical in nature.

Third, the findings supported the notion that ITCAP are a critical element that can strengthen the bank's leading indicators. Studies show that the mismatch between ITCAP and marketing practices practiced by marketing managers in the Algerian banking sector will hinder improvement initiatives. Thus, the marketing strategies of these banks and their proper ITCAP should be developed. Finally, as mentioned at the beginning of this study, in a turbulent environment, it is very difficult for banks to grow or even live without being entrepreneurs (Lumpkin and Dess, 2001). Specifically, entrepreneurship practices in banks help grow and thrive in a competitive environment.

Therefore, the results of this study suggested that policymakers in the banking sector in Algeria should seriously consider the development of marketing practices for their direct role in the entrepreneurship of organizations and their ownership of the causes of environmental risks and seize marketing opportunities and survival in this competitive era. Specifically, the moderate role of ITCAP has suggested that an effective alignment of the bank's ITCAP with its entrepreneurial marketing practices can enhance the bank's entrepreneurship position, and can also enhance marketing managers' perception of the seriousness of their banks in promoting a corporate entrepreneurial culture. Consequently, the above findings and discussions summarize that MM practices have been an important potential indicator of entrepreneurship in the banking sector in Algeria. Therefore, it is necessary to pay attention to the importance of these factors to promote entrepreneurship in the service sector.

\section{Limitations and future research}

First, it is essential to mention that the data on entrepreneurship presented in this study were of a personal nature. Although researchers have shown that subjective data are valid and reliable for entrepreneurship assessment (Dechow, 2012), on the contrary, the researchers also argued that subjective measures are subject to many types of judicial biases (Schulte et al., 2015). Although, objective data were not readily obtained (Judd et al., 2001). However, the objective measure will further enhance the results. Therefore, future research using objective measures is needed to further validate the results of this study. Second, it is very difficult to present the generalization of the results of this study because the study sample was mainly driven by some of the major banks in Algeria and in particular, covering the main cities of the country. Therefore, it would be appropriate to include other banks in Algeria in the study sample to improve the generalization of results. Banks can also be studied and compared with other financial institutions in the country for their comprehensive understanding of the entire financial sector and its prospects.

\section{Moderating effect of information technology}

113 
PRR

5,2

Third, in this study, the research model showed $53 \%$ of the difference. This suggests that other factors may specifically explain and explore the disparity in entrepreneurship. Future researchers may therefore consider other factors that can improve entrepreneurship. In particular, further investigation of this phenomenon is encouraged in service-based industries such as health care, education, insurance and hotel industries. Finally, the study presented tests potentially moderate impact of ITCAP on the relationship between MM and entrepreneurship. This states that ITCAP is a critical element in promoting entrepreneurship by helping organizations to strengthen their marketing practices. In the future, researchers may make further efforts to determine how ITCAP can help organizations enhance their performance and enhance their entrepreneurial capacity. In doing so, researchers may also try to answer questions such as the type of ITCAP that enhances the MM and ultimately leads to entrepreneurship.

\section{Conclusion}

While extant research has established a positive relationship between $\mathrm{MM}$ and $\mathrm{CE}$, the present study argues that this relationship may depend on contextual factors (Rodan and Galunic, 2004). Consequently, this study incorporated and tested ITCAP as a boundary condition between MM and CE relationship.

Therefore, the primary contribution of the present study lies in having found to moderate the relationship between MM and $\mathrm{CE}$ (Wu and Zumbo, 2008). Additionally, this study contributed to scholarship by focusing on Algeria banking sector, which has been largely ignored by previous studies despite the contribution of this sector to economic development. The results suggest that when MM and ITCAP interact together, superior entrepreneurship is likely to be achieved. Thus, if ITCAP are adopted and implemented by business organizations in general and banks in particular, in the context of linking ITCAP with indicators of entrepreneurial behavior, banks are likely to make a leading position and outstanding performance.

\section{References}

Abro, Q.M.M., Memon, N.A. and Arshdi, P.I.S. (2011), "Dynamic capabilities and firm performance: a case of two SMEs in Pakistan", Mehran University Research Journal of Engineering and Technology, Vol. 30 No. 3, pp. 521-532.

Ajayi, B. (2016), "The impact of entrepreneurial orientation and networking capabilities on the export performance of Nigerian agricultural SMEs", Journal of Entrepreneurship and Innovation in Emerging Economies, Vol. 2 No. 1, pp. 1-23, doi: 10.1177/2393957515619720.

Amit, R. and Zott, C. (2001), "Value creation in e-business", Strategic Management Journal, Vol. 22 Nos 6/7, pp. 493-520, doi: 10.1002/smj.187.

Arora, A. and Nandkumar, A. (2012), "Insecure advantage? Markets for technology and the value of resources for entrepreneurial ventures”, Strategic Management Journal, Vol. 33 No. 3, pp. 231-251, doi: $10.1002 /$ smj.953.

Baron, R.M. and Kenny, D.A. (1986), "The moderator-mediator variable distinction in social psychological research: conceptual”, Journal of Personality and Social Psychology, Vol. 51 No. 6, pp. 1173-1182.

Barrett, H., Balloun, J.L. and Weinstein, A. (2000), "Marketing mix factors as moderators of the corporate entrepreneurship - business performance relationship - a multistage, multivariate analysis", Journal of Marketing Theory and Practice, Vol. 8 No. 2, pp. 50-62, doi: 10.1080/ 10696679.2000.11501868. 
Bashar, A., Ahmad, I. and Wasiq, M. (2012), "Effectiveness of social media as a marketing tool: an empirical study", International Journal of Marketing, Financial Services and Management Research, Vol. 1, available at: www.indianresearchjournals.com

Bharadwaj, A.S. (2000), "A resource-based perspective on information technology capability and firm performance: an empirical investigation”, MIS Quarterly, Vol. 24 No. 1, pp. 169-193, doi: 10.2307/ 3250983.

Bhuian, S.N., Menguc, B. and Bell, S.J. (2005), "Just entrepreneurial enough: the moderating effect of entrepreneurship on the relationship between market orientation and performance", Journal of Business Research, Vol. 58 No. 1, pp. 9-17, doi: 10.1016/S0148-2963(03)00074-2.

Bilal, Z.O. and Al Mqbali, N.S. (2015), "Challenges and constrains faced by small and medium enterprises (SMEs) in Al Batinah governorate of Oman", World Journal of Entrepreneurship, Management and Sustainable Development, Vol. 11 No. 2, pp. 120-130, doi: 10.1108/wjemsd-05-2014-0012.

Bocconcelli, R., Cioppi, M., Fortezza, F., Francioni, B., Pagano, A., Savelli, E. and Splendiani, S. (2018), "SMEs and marketing: a systematic literature review", International Journal of Management Reviews, Vol. 20 No. 2, pp. 227-254, doi: 10.1111/ijmr.12128.

Bolin, J.H. (2014), "Introduction to mediation, moderation, and conditional process analysis: a regression-based approach. New York, NY: the Guilford press", Journal of Educational Measurement, Vol. 51 No. 3, pp. 335-337, doi: 10.1111/jedm.12050.

Bonett, D.G. and Wright, T.A. (2015), "Cronbach's alpha reliability: interval estimation, hypothesis testing, and sample size planning", Journal of Organizational Behavior, Vol. 36 No. 1, pp. 3-15, doi: $10.1002 /$ job.1960.

Brouthers, K.D., Nakos, G. and Dimitratos, P. (2015), "SME entrepreneurial orientation, international performance, and the moderating role of strategic alliances", Entrepreneurship Theory and Practice, Vol. 39 No. 5, pp. 1161-1187, doi: 10.1111/etap.12101.

Bucktowar, R., Kocak, A. and Padachi, K. (2015), "Entrepreneurial orientation, market orientation and networking: impact on innovation and firm performance", Journal of Developmental Entrepreneurship, Vol. 20 No. 4, doi: 10.1142/S1084946715500247.

Byrd, T.A. and Turner, D.E. (2001), "An exploratory examination of the relationship between flexible IT infrastructure and competitive advantage”, Information and Management, Vol. 39 No. 1, pp. 41-52, doi: 10.1016/S0378-7206(01)00078-7.

Carson, D., Cromie, S., Mcgowan, P. and Hill, J. (1995), "Marketing and entrepreneurship in SMEs", European Journal of Marketing, Vol. 296, available at: www.amazon.com/MarketingEntrepreneurship-SMEs-Innovative-Approach/dp/0131509705

Chae, H.C., Koh, C.E. and Park, K.O. (2018), "Information technology capability and firm performance: role of industry", Information and Management, Vol. 55 No. 5, pp. 525-546, doi: 10.1016/j.im.2017.10.001.

Chae, H.C., Koh, C.E. and Prybutok, V.R. (2014), "Information technology capability and firm performance: contradictory findings and their possible causes", MIS Quarterly, Vol. 38 No. 1, pp. 305-326, doi: 10.25300/MISQ/2014/38.1.14.

Chen, Y., Wang, Y., Nevo, S., Benitez-Amado, J. and Kou, G. (2015), "IT capabilities and product innovation performance: the roles of corporate entrepreneurship and competitive intensity", Information and Management, Vol. 52 No. 6, pp. 643-657, doi: 10.1016/j.im.2015.05.003.

Chen, Y., Wang, Y., Nevo, S., Jin, J., Wang, L. and Chow, W.S. (2014), "IT capability and organizational performance: the roles of business process agility and environmental factors", European Journal of Information Systems, Vol. 23 No. 3, pp. 326-342, doi: 10.1057/ejis.2013.4.

Colbert, F. (2003), "Entrepreneurship and leadership in marketing the arts", International Journal of Arts Management, Vol. 6 No. 1, pp. 30-39, doi: 10.2307/41064806.

Collinson, E. and Shaw, E. (2001), "Entrepreneurial marketing - a historical perspective on development and practice", Management Decision, Vol. 39 No. 9, pp. 761-766, doi: 10.1108/ EUM0000000006221. 
PRR

5,2

Corneliu, B. and Maria, A.F. (2013), "Measuring service quality in banks using SERVQUAL", Contemporary Legal and Economic Issues, Vol. 4, pp. 260-292, available at: http://search. ebscohost.com/login.aspx?direct=true\&db=aph\&AN=113492313\&lang=pt-br\&site=ehostlive\&authtype $=$ ip, cookie, uid

Dangolani, S.K. (2011), "The effect of information technology in the entrepreneurship (a case study in Golestan province Iran)", Procedia - Social and Behavioral Sciences, Vol. 30, pp. 10-12, doi: 10.1016/j.sbspro.2011.10.002.

Dechow, N. (2012), "The balanced scorecard: subjects, concept and objects - a commentary”, Journal of Accounting and Organizational Change, Vol. 8 No. 4, pp. 511-527, doi: 10.1108/ 18325911211273509 .

Jerome, M. (2019), “The marketing mix marketing mix definition of the 4P's and 7P's”, Mark Acutt and Patrick Kuo, available at: http://marketingmix.co.uk

Goforth, C. (2015), Using and Interpreting Cronbach's Alpha, University of VT Library.

Goodale, J.C., Kuratko, D.F., Hornsby, J.S. and Covin, J.G. (2011), "Operations management and corporate entrepreneurship: the moderating effect of operations control on the antecedents of corporate entrepreneurial activity in relation to innovation performance", Journal of Operations Management, Vol. 29 Nos 1/2, pp. 116-127, doi: 10.1016/j.jom.2010.07.005.

Haar, J.M. and White, B.J. (2013), "Corporate entrepreneurship and information technology towards employee retention: a study of New Zealand firms", Human Resource Management Journal, Vol. 23 No. 1, pp. 109-125, doi: 10.1111/j.1748-8583.2011.00178.x.

Hacioglu, G., Eren, S.S., Eren, M.S. and Celikkan, H. (2012), “The effect of entrepreneurial marketing on firms' innovative performance in Turkish SMEs", Procedia - Social and Behavioral Sciences, Vol. 58, pp. 871-878, doi: 10.1016/j.sbspro.2012.09.1065.

Hamid, M.R.A., Mustafa, Z., Idris, F., Abdullah, M. and Suradi, N.R.M. (2011), "Measuring value -based productivity: a confirmatory factor analytic (CFA) approach", International Journal of Business and Social Science, Vol. 2 No. 6, pp. 85-93, available at: www.ijbssnet.com/journals/Vol._2_No. _6\%3B_April_2011/10.pdf

Harrigan, P., Ramsey, E. and Ibbotson, P. (2012), "Entrepreneurial marketing in SMEs: the key capabilities of e-CRM", Journal of Research in Marketing and Entrepreneurship, Vol. 14 No. 1, pp. 40-64, doi: 10.1108/14715201211246760.

Hayes, A.F. (2012), "PROCESS: a versatile computational tool for observed variable moderation, mediation, and conditional process modeling", Manuscript Submitted for Publication, pp. 1-39, available at: www.afhayes.com/public/process2012.pdf

Hayes, A. (2016), "No Title The PROCESS macro for SPSS and SAS".

Hayes, A.F. and Rockwood, N.J. (2017), "Regression-based statistical mediation and moderation analysis in clinical research: observations, recommendations, and implementation”, Behaviour Research and Therapy, Vol. 98, pp. 39-57, doi: 10.1016/j.brat.2016.11.001.

Henseler, J., Ringle, C.M. and Sarstedt, M. (2012), "Using partial least squares path modeling in advertising research: basic concepts and recent issues", Handbook of Research on International Advertising, Edward Elgar Publishing, pp. 252-276, doi: 10.4337/9781781001042.00023

Hoffman, B.W., Sellers, R.D. and Skomra, J. (2018), "The impact of client information technology capability on audit pricing", International Journal of Accounting Information Systems, Vol. 29, pp. 59-75, doi: 10.1016/j.accinf.2018.03.002.

Hultman, C.M. and Hills, G.E. (2011), "Influence from entrepreneurship in marketing theory", Journal of Research in Marketing and Entrepreneurship, Vol. 13 No. 2, pp. 120-125, doi: 10.1108/ 14715201111176408.

Ireland, R.D., Hitt, M.A. and Sirmon, D.G. (2003), "A model of strategic enterpreneurship: the construct and its dimensions”, Journal of Management, Vol. 29 No. 6, pp. 963-989, doi: 10.1016/S0149-2063 (03)00086-2. 
Išoraite, M. (2015), “Analysis of marketing mix: Nivea case study”, Entrepreneurship and Sustainability Issues, Vol. 3 No. 2, pp. 173-185, doi: 10.9770/jesi.2015.3.2(5).

Jarque, C.M. and Bera, A.K. (1987), "A test for normality of observations and regression residuals", International Statistical Review/Revue Internationale de Statistique, Vol. 55 No. 2, p. 163, doi: $10.2307 / 1403192$.

Judd, C.M., Kenny, D.A. and McClelland, G.H. (2001), "Estimating and testing mediation and moderation in within-subject designs", Psychological Methods, Vol. 6 No. 2, pp. 115-134, doi: 10.1037/1082-989X.6.2.115.

Karimi, J. and Walter, Z. (2016), "Corporate entrepreneurship, disruptive business model innovation adoption, and its performance: the case of the newspaper industry", Long Range Planning, Vol. 49 No. 3, pp. 342-360, doi: 10.1016/j.lrp.2015.09.004.

Kivipõld, K. and Vadi, M. (2013), "Market orientation in the context of the impact of leadership capability on performance", International Journal of Bank Marketing, Vol. 31 No. 5, pp. 368-387, doi: 10.1108/IJBM-09-2012-0092.

Knight, G. (2000), "Entrepreneurship and marketing strategy: the SME under globalization”, Journal of International Marketing, Vol. 8 No. 2, pp. 12-32, doi: 10.1509/jimk.8.2.12.19620.

Kraus, S., Harms, R. and Fink, M. (2010), "Entrepreneurial marketing: moving beyond marketing in new ventures", International Journal of Entrepreneurship and Innovation Management, Vol. 11 No. 1, pp. 19-34, doi: 10.1504/IJEIM.2010.029766.

Kuratko, D.F. (2007), "Entrepreneurial leadership in the 21st century", Journal of Leadership and Organizational Studies, Vol. 13 No. 4, pp. 1-11, doi: 10.1177/10717919070130040201.

Kuratko, D.F. (2010), "Corporate entrepreneurship: an introduction and research review", Handbook of Entrepreneurship Research, Springer, New York, NY, pp. 129-163, doi: 10.1007/978-1-4419-1191-9_6

Lee, J. (2002), "A key to marketing financial services: the right mix of products, services, channels and customers", Journal of Services Marketing, Vol. 16 No. 3, pp. 238-258, doi: 10.1108/ 08876040210427227.

Lekmat, L., Selvarajah, C. and Hewege, C. (2018), "Relationship between market orientation, entrepreneurial orientation, and firm performance in Thai SMEs: the mediating role of marketing capabilities laddawan”, Doğus Üniversitesi Dergisi, doi: 10.31671/dogus.2018.27.

Li, L., Su, F., Zhang, W. and Mao, J.Y. (2018), "Digital transformation by SME entrepreneurs: a capability perspective", Information Systems Journal, Vol. 28 No. 6, pp. 1129-1157, doi: 10.1111/ isj.12153.

Lumpkin, G.T. and Dess, G.G. (2001), "Linking two dimensions of entrepreneurial orientation to firm performance: the moderating role of environment and industry life cycle", Journal of Business Venturing, Vol. 16 No. 5, pp. 429-451, doi: 10.1016/S0883-9026(00)00048-3.

Martens, C.D.P., Machado, F.J., Martens, M.L., Silva, F.Q.P., de, O.e. and Freitas, H.M.R.D. (2018), "Linking entrepreneurial orientation to project success", International Journal of Project Management, Vol. 36 No. 2, pp. 255-266, doi: 10.1016/j.ijproman.2017.10.005.

Martin, D.M. (2009), "The entrepreneurial marketing mix", Qualitative Market Research: An International Journal, Vol. 12 No. 4, pp. 391-403, doi: 10.1108/13522750910993310.

Miles, M.P. and Darroch, J. (2006), "Large firms, entrepreneurial marketing processes, and the cycle of competitive advantage", European Journal of Marketing, Vol. 40 Nos 5/6, pp. 485-501, doi: 10.1108/03090560610657804.

Miles, M., Gilmore, A., Harrigan, P., Lewis, G. and Sethna, Z. (2015), "Exploring entrepreneurial marketing", Journal of Strategic Marketing, Vol. 23 No. 2, pp. 94-111, doi: 10.1080/ 0965254X.2014.914069.

Mithas, S., Ramasubbu, N. and Sambamurthy, V. (2011), "How information management capability influences firm performance", MIS Quarterly: Management Information Systems, Vol. 35 No. 1, pp. 237-256, doi: 10.2307/23043496.
Moderating effect of information technology 
PRR

5,2

Morris, M.H. and Lewis, P.S. (1995), "The determinants of entrepreneurial activity”, European Journal of Marketing, Vol. 29 No. 7, pp. 31-48, doi: 10.1108/03090569510094991.

Muñoz, C.A., Mosey, S. and Binks, M. (2011), "Developing opportunity-identification capabilities in the classroom: visual evidence for changing mental frames", Academy of Management Learning and Education, Vol. 10 No. 2, pp. 277-295, doi: 10.5465/AMLE.2011.62798934.

Nasution, H.N., Mavondo, F.T., Matanda, M.J. and Ndubisi, N.O. (2011), "Entrepreneurship: its relationship with market orientation and learning orientation and as antecedents to innovation and customer value", Industrial Marketing Management, Vol. 40 No. 3, pp. 336-345, doi: 10.1016/ j.indmarman.2010.08.002.

Ndubisi, N.O. and Iftikhar, K. (2012), "Relationship between entrepreneurship, innovation and performance: comparing small and medium-size enterprises", Journal of Research in Marketing and Entrepreneurship, Vol. 14 No. 2, pp. 214-236, doi: 10.1108/14715201211271429.

O'Reilly, N.M., Robbins, P. and Scanlan, J. (2019), "Dynamic capabilities and the entrepreneurial university: a perspective on the knowledge transfer capabilities of universities", Journal of Small Business and Entrepreneurship, Vol. 31 No. 3, pp. 243-263, doi: 10.1080/ 08276331.2018.1490510.

Oflac, B.S., Dobrucal, B., Yavas, T. and Escobar, M.G. (2015), "Services marketing mix efforts of a global services brand: the case of DHL logistics", Procedia Economics and Finance, Vol. 23, pp. 1079-1083, doi: 10.1016/s2212-5671(15)00457-8.

Oh, S., Yang, H. and Kim, S.W. (2014), "Managerial capabilities of information technology and firm performance: role of e-procurement system type", International Journal of Production Research, Vol. 52 No. 15, pp. 4488-4506, doi: 10.1080/00207543.2013.867084.

Pingsmann, A., Freedman, K.B. and Bernstein, J. (2000), "Sample size and statistical power [5] (multiple letters)”, Journal of Bone and Joint Surgery - Series A, Vol. 82 No. 9, p. 1361, doi: 10.2106/ 00004623-200009000-00028.

Prado, P.H.M., Korelo, J.C. and Silva, D.M.L.D. (2014), "Mediation, moderation and conditional process analysis", Revista Brasileira de Marketing, Vol. 13 No. 4, pp. 4-24, doi: 10.5585/remark. v13i4.2739.

Ramachandran, K. and Ray, S. (2006), "Networking and new venture resource strategies”, The Journal of Entrepreneurship, Vol. 15 No. 2, pp. 145-168, doi: 10.1177/097135570601500203.

Rehman, N., Nor, M.N.M., Taha, A.Z. and Mahmood, S. (2018), "Impact of information technology capabilities on firm performance: understanding the mediating role of corporate entrepreneurship in SMES", Academy of Entrepreneurship Journal, No. 3, p. 24.

Rodan, S. and Galunic, C. (2004), "more than network structure: how knowledge heterogeneity influences managerial performance and innovativeness", Strategic Management Journal, Vol. 25 No. 6, pp. 541-562, doi: 10.1002/smj.398.

Schulte, E.-M., Lehmann-Willenbrock, N. and Kauffeld, S. (2015), “Treat Us fairly and We won’t complain: multilevel effects of procedural justice on complaining behavior in team meetings", Psychology, Vol. 06 No. 14, pp. 1795-1810, doi: 10.4236/psych.2015.614176.

Shepherd, D.A., Williams, T.A. and Patzelt, H. (2015), "Thinking about entrepreneurial decision making: review and research agenda", Journal of Management, Vol. 41 No. 1, pp. 11-46, doi: $10.1177 / 0149206314541153$.

Simba, A. (2015), "A new model of knowledge and innovative capability development for small bornglobal bio-tech firms: evidence from the east Midlands, UK", International Journal of Entrepreneurship and Innovation Management, Vol. 19 Nos 1/2, pp. 30-58, doi: 10.1504/ IJEIM.2015.068421.

Solé, M. (2013), "Entrepreneurial marketing: conceptual exploration and link to performance", Journal of Research in Marketing and Entrepreneurship, Vol. 15 No. 1, pp. 23-38, doi: 10.1108/JRME-072012-0020. 
Stokes, D. (2000), "Putting entrepreneurship into marketing: the processes of entrepreneurial marketing", Journal of Research in Marketing and Entrepreneurship, Vol. 2 No. 1, pp. 1-16, doi: $10.1108 / 14715200080001536$.

Sulistyo, H. and Siyamtinah, (2016), "Innovation capability of SMEs through entrepreneurship, marketing capability, relational Capital and empowerment", Asia Pacific Management Review, Vol. 21 No. 4, pp. 196-203, doi: 10.1016/j.apmrv.2016.02.002.

Sutton, R.I., Staw, B.M., Quarterly, A.S. and Sep, N. (2007), "What theory is not", Administrative Science Quarterly, Vol. 40 No. 3, pp. 371-384.

Moderating effect of information technology

Trainor, K.J., Rapp, A., Beitelspacher, L.S. and Schillewaert, N. (2011), "Integrating information technology and marketing: an examination of the drivers and outcomes of e-marketing capability", Industrial Marketing Management, Vol. 40 No. 1, pp. 162-174, doi: 10.1016/j. indmarman.2010.05.001.

Urbano, D. and Alvarez, C. (2014), "Institutional dimensions and entrepreneurial activity: an international study", Small Business Economics, Vol. 42 No. 4, pp. 703-716, doi: 10.1007/s11187013-9523-7.

Wahab, H.A. and Nagaty, S.A. (2017), "Analyzing the relationship between market orientation and corporate entrepreneurship", European Journal of Business and Management Www.Iiste.Org ISSN, Vol. 9 No. 29, pp. 42-52, available at: www.iiste.org

Walter, A., Auer, M. and Ritter, T. (2006), "The impact of network capabilities and entrepreneurial orientation on university spin-off performance", Journal of Business Venturing, Vol. 21 No. 4, pp. 541-567, doi: 10.1016/j.jbusvent.2005.02.005.

Weerawardena, J. (2003), "The role of marketing capability in innovation-based competitive strategy", Journal of Strategic Marketing, Vol. 11 No. 1, pp. 15-35, doi: 10.1080/0965254032000096766.

Whetten, D.A. (2014), "A constitutes theoretical contribution”?, Academy of Management Review, Vol. 14 No. 4, pp. 490-495.

Wu, A.D. and Zumbo, B.D. (2008), "Understanding and using mediators and moderators", Social Indicators Research, Vol. 87 No. 3, pp. 367-392, doi: 10.1007/s11205-007-9143-1.

Yelkur, R. (2000), "Customer satisfaction and the services marketing mix", Journal of Professional Services Marketing, Vol. 21 No. 1, pp. 105-115, doi: 10.1300/J090v21n01_07.

Zahra, S.A. and George, G. (2002), "The net-enabled business innovation cycle and the evolution of dynamic capabilities", Information Systems Research, Vol. 13 No. 2, pp. 147-150, doi: 10.1287/ isre.13.2.147.90.

\section{Further reading}

101 rapport annuel 2017 evolution economique et monetaire en algerie (2018),

Kaplan, R.S. (2009), "Conceptual foundations of the balanced scorecard”, Handbooks of Management Accounting Research, doi: 10.1016/S1751-3243(07)03003-9.

\section{Corresponding author}

Fatima Ghezali can be contacted at: maghazeli@gmail.com

For instructions on how to order reprints of this article, please visit our website:

www.emeraldgrouppublishing.com/licensing/reprints.htm

Or contact us for further details: permissions@emeraldinsight.com 